\title{
Clinicopathological Characteristics of Primary Ovarian Adenomyoma: A Single-institutional Experience
}

\author{
KIYONG NA ${ }^{1}$, SUNG YOON PARK ${ }^{2}$ and HYUN-SOO KIM ${ }^{1}$ \\ ${ }^{1}$ Department of Pathology, Severance Hospital, Yonsei University College of Medicine, Seoul, Republic of Korea; \\ ${ }^{2}$ Department of Radiology and Research Institute of Radiological Science, \\ Yonsei University College of Medicine, Seoul, Republic of Korea
}

\begin{abstract}
Adenomyoma is a benign neoplasm composed of endometrial-type glands, specialized endometrial-type stroma, and well-formed smooth muscle bundles. This tumor typically originates within the uterus, whereas extrauterine adenomyoma is an unusual presentation. The ovary is the most common site of extrauterine adenomyoma. In this study, we describe the clinical and pathological features and immunohistochemical findings of primary ovarian adenomyoma in patients at our Institution. In addition, we provide a thorough review of previously published cases of primary ovarian adenomyoma and clarify their clinicopathological characteristics. The most common clinical presentations of ovarian adenoma were abdominopelvic pain and abnormal menstruation. Imaging features of ovarian adenomyoma varied, showing mixed solid and cystic, solid, or cystic masses. Frequently associated conditions included congenital anomalies of the urinary tract and endometriosis. Although most cases of ovarian adenomyoma exhibit benign histopathological features, we observed one case of endometrioid carcinoma arising in ovarian adenomyoma. Clinical follow-up data indicated that simple excision of the mass is curative for ovarian adenomyoma, but certain patients underwent unnecessary surgical procedures due to lack of awareness of primary ovarian adenomyoma and high index of suspicion for malignancy in patients with solid ovarian masses. Although ovarian adenomyoma is rare, awareness of this tumor type aids pathologists in making correct diagnoses and clinicians in avoiding unwarranted therapeutic procedures.
\end{abstract}

Correspondence to: Hyun-Soo Kim, Department of Pathology, Severance Hospital, Yonsei University College of Medicine, 50-1, Yonsei-ro, Seodaemun-gu, Seoul 03722, Republic of Korea. Tel: +82 222281794, +82 23620860, e-mail: hyunsookim@yuhs.ac

Key Words: Ovary, adenomyoma, extrauterine adenomyoma, uteruslike mass, endomyometriosis.
Extrauterine adenomyoma is a rare type of benign tumor composed of endometrial-type glands and stroma and surrounded by a well-formed smooth muscle coat (1). This tumor type can arise from the ovary (1-14), uterine ligament (15-23), peritoneum (24-27), conus medullaris (28-30), or intestine (31-35). The ovary is the most common site of extrauterine adenomyoma. Most patients with ovarian adenomyoma are of childbearing age. Simple excision of the mass is curative for ovarian adenomyoma, but previous studies documented that patients sometimes undergo unnecessary surgical procedures due to lack of awareness of primary ovarian adenomyoma and high index of suspicion for malignancy in patients with ovarian solid lesions (11-13). Awareness of this rare tumor type helps pathologists make correct diagnoses and clinicians to avoid unwarranted therapeutic procedures.

We reviewed previously reported cases of ovarian adenomyoma in the context of our recent experiences with primary ovarian adenomyoma. To the best of our knowledge, only 16 cases of primary ovarian adenomyoma have been documented in the English literature (1-14). In this study, we describe clinical and pathological features and immunohistochemical findings of primary ovarian adenomyoma. In addition, we provide a thorough review of previously published cases and clarify the clinicopathological characteristics of this tumor type. Comprehensive analyses of cases expand our knowledge regarding primary ovarian adenomyoma.

\section{Patients and Methods}

Case selection. The cases included in this study were selected from the computerized database of Severance Hospital, Yonsei University College of Medicine. A thorough search was performed using the key words "ovary," "adenomyoma," "ovarian adenomyoma," "extrauterine adenomyoma," "uterine-like mass," "uterus-like mass," "uterus-like ovarian mass," and "endomyometriosis" in a search of archival surgical pathology cases. During the study period, from August 2007 to July 2016, 447 patients were diagnosed with adenomyoma or adenomyomatous lesions, including adenomyomatosis of the gallbladder $(322 / 447 ; 72.0 \%)$, uterine adenomyoma $(88 / 447 ; 19.7 \%)$, 
endometrial polyp with adenomyomatous morphology $(22 / 447 ; 4.9 \%)$, endometrial atypical polypoid adenomyoma $(6 / 447 ; 1.3 \%)$, endocervical polypoid adenomyoma $(4 / 447 ; 0.9 \%)$, primary ovarian adenomyoma $(3 / 447 ; 0.7 \%)$, adenomyoma of the ampulla of Vater $(1 / 447 ; 0.2 \%)$, and adenomyoma of the small intestine $(1 / 447 ; 0.2 \%)$. Clinical and pathological information was obtained from the electronic medical information system and pathology reports. The clinical details that were reviewed included age of the patient at diagnosis, parity, associated congenital anomalies, coexisting medical conditions, presumptive clinical diagnosis, imaging findings, treatment, and current status with follow-up period. The pathological information included location of tumor, number, and greatest dimension of tumor, histopathological diagnosis, the presence of residual ovarian parenchyma, uterine pathology (in patients who underwent hysterectomy), unusual histopathological findings, and the application ancillary technique (immunohistochemistry). This study was reviewed and approved by the Institutional Review Board at Severance Hospital, Yonsei University Health System, Seoul, Republic of Korea (20161925-001).

Histopathology. Resected specimens were fixed in $10 \%$ neutralbuffered formalin and embedded in paraffin blocks. We cut and stained $4-\mu \mathrm{m}$ sections from each formalin-fixed, paraffin-embedded block with hematoxylin and eosin. Among these, the most representative slide, containing an appropriate volume of tumor and possibly normal ovarian tissue, was chosen for immunohistochemical staining.

Immunohistochemistry. The formalin-fixed, paraffin-embedded sections were deparaffinized and rehydrated using xylene and alcohol. Immunohistochemical staining was performed using the Ventana Benchmark XT automated staining system (Ventana Medical Systems, Tucson, AZ, USA) or Dako Omnis (Dako, Agilent Technologies, Carpinteria, CA, USA), according to the manufacturer's instructions (36-45). Antigen retrieval was performed using Cell Conditioning Solution (CC1; Ventana Medical Systems) or EnVision FLEX Target Retrieval Solution, High pH (Dako, Agilent Technologies). Sections were incubated with primary antibodies to: caldesmon (dilution 1:400; clone hCD; Dako), CD10 (dilution 1:50; clone 56C6; Novocastra, Leica Biosystems, Newcastle Upon Tyne, UK), cytokeratin 7 (dilution 1:100; clone OV-TL 12/30; Dako), desmin (dilution 1:500; clone D33; Dako), epithelial membrane antigen (dilution 1:200; clone E29; Dako), estrogen receptor (dilution 1:150; clone 6F11; Novocastra), Ki-67 (dilution 1:150; clone MIB-1; Dako), musclespecific actin (dilution 1:50; clone HHF35; Dako), progesterone receptor (dilution 1:100; clone 16; Novocastra), smooth muscle actin (dilution 1:500; clone 1A4; Dako), and inhibin- $\alpha$ (1:50; BioRad Laboratories, Hercules, CA, USA). After chromogenic visualization using ultraView Universal DAB Detection Kits (Ventana Medical Systems) or EnVision FLEX /HRP (Dako, Agilent Technologies), slides were counterstained with hematoxylin. Appropriate positive and negative controls were stained concurrently to validate the staining method.

Literature review. We thoroughly searched the Medline database using the PubMed retrieval service. Searches were performed in July 2016, using the key words "ovary," "adenomyoma," "ovarian adenomyoma," "extrauterine adenomyoma," "uterine-like mass," "uterus-like mass," "uterus-like ovarian mass," and "endomyometriosis."

\section{Results}

Case presentation. Case 1: A 43-year-old nulliparous woman was admitted to the Gynecology Department for low abdominal pain and dyspareunia of 3 months' duration. Her menstruation history revealed menometrorrhagia. She complained of difficult pregnancy in the previous 8 months. Her past medical history was remarkable for ovarian endometriosis and recurrent uterine leiomyomata, which were managed by right salpingo-oophorectomy and myomectomy. Abdominopelvic physical examination was unremarkable. Routine blood tests and serum cancer antigen125 (CA-125) level were within normal ranges. Pelvic ultrasonography revealed an enlarged, globular uterus with subserosal and intramural leiomyomata. The left adnexa had a $4.7 \times 3.3 \mathrm{~cm}$ anechoic, septated cystic mass. With a presumptive clinical diagnosis of uterine leiomyomata and ovarian endometriosis, the patient underwent total abdominal hysterectomy and left salpingo-oophorectomy.

Case 2: A 36-year-old primiparous woman was admitted to the Gynecology Department with low abdominal pain that had gradually increased for 2 months. Her menstruation history revealed hypermenorrhea and dysmenorrhea. Her past medical history showed ovarian endometriosis managed by cystectomy. Abdominopelvic physical examination was unremarkable. Routine blood tests and serum CA-125 level were within normal ranges. Ultrasonographic examination at an outside hospital raised the suspicion of recurrent ovarian endometriosis, hydrosalpinx, and uterine adenomyosis. Magnetic resonance imaging demonstrated multiple, highsignal dots in the uterus and left adnexa on T1-weighted images. T2-weighted images revealed a $1.7 \mathrm{~cm}$ dark signal nodule in the left adnexa. With a presumptive clinical diagnosis of uterine adenomyosis and ovarian endometriosis, the patient underwent total abdominal hysterectomy with left ovarian wedge resection and left salpingectomy.

Case 3: A 45-year-old nulliparous woman was admitted with a pelvic mass incidentally detected on routine ultrasonographic examination. Her menstruation history revealed dysmenorrhea. She denied any other relevant medical history. Abdominopelvic physical examination was unremarkable. Computed tomography demonstrated multiple subserosal and intramural masses in the uterus. Bilateral adnexae were unremarkable. The patient was scheduled for total hysterectomy with bilateral salpingectomy. Intraoperative inspection revealed protruding uterine masses and multiple tan-white masses in the retroperitoneum. The right ovary showed a round $0.8 \mathrm{~cm}$ mass with central cystic changes. The patient underwent total abdominal hysterectomy with right ovarian wedge resection, right salpingectomy, left salpingo-oophorectomy, and retroperitoneal mass excision.

In our three patients, gross examination of the ovary revealed well-circumscribed, ovoid, white, rubbery masses, 
Table I. Clinical features of primary ovarian adenomyoma.

\begin{tabular}{|c|c|c|c|c|c|c|c|}
\hline Case & Author (year) (ref) & $\begin{array}{l}\text { Age, } \\
\text { years }\end{array}$ & Parity & Congenital anomaly & $\begin{array}{l}\text { Associated } \\
\text { conditions }\end{array}$ & $\begin{array}{c}\text { Clinical } \\
\text { presentations }\end{array}$ & $\begin{array}{c}\text { Clinical } \\
\text { diagnosis }\end{array}$ \\
\hline 1 & Cozzutto (1981) (1) & 31 & 0 & Unilateral renal agenesis & Endometriosis & Left pelvic pain & NA \\
\hline 2 & $\begin{array}{l}\text { Pueblitz-Peredo et al. } \\
\text { (1985) (2) }\end{array}$ & 18 & 0 & $\begin{array}{l}\text { Double renal excretory } \\
\text { system, double ureter }\end{array}$ & None & $\begin{array}{l}\text { Pelvic pain, } \\
\text { lower extremity } \\
\text { paresthesia }\end{array}$ & NA \\
\hline 3 & McDougal et al. (1986) (3) & 36 & NA & None & None & Right ovarian mass & NA \\
\hline 4 & Rahilly et al. (1991) (4) & 38 & 0 & None & $\begin{array}{l}\text { EM cancer, } \\
\text { ureteral calculus }\end{array}$ & Right pelvic pain & NA \\
\hline 5 & Verhest et al. (1996) (5) & NA & NA & None & None & LAP, menorrhagia & NA \\
\hline 6 & Mitra et al. (1997) (6) & 34 & 1 & None & None & $\begin{array}{l}\text { Menorrhagia, } \\
\text { foul-smelling } \\
\text { discharge }\end{array}$ & NA \\
\hline 7 & Pai et al. (1998) (7) & 38 & 0 & None & Breast carcinoma & Incidental & Krukenberg tumor \\
\hline 8 & & 43 & 2 & None & None & Pelvic mass & Ovarian cancer \\
\hline 9 & & 39 & 2 & None & Breast carcinoma, LM & LAP & NA \\
\hline 10 & Shutter (2005) (8) & 11 & 0 & $\begin{array}{l}\text { Unilateral pelvic kidney, } \\
\text { ureteral reimplantation, } \\
\text { vesicoureteral reflux }\end{array}$ & $\begin{array}{l}\text { Recent menarche, } \\
\text { hydrosalpinx }\end{array}$ & $\begin{array}{l}\text { Right upper } \\
\text { quadrant pain }\end{array}$ & $\begin{array}{c}\text { Teratoma or } \\
\text { endometriotic cyst }\end{array}$ \\
\hline 11 & Bayar et al. (2006) (9) & 38 & 0 & None & Unexplained infertility & Pelvic pain & NA \\
\hline 12 & Gurel et al. (2007) (10) & 54 & 0 & None & $\begin{array}{l}\text { Adenomyosis, LM, } \\
\text { menopause }\end{array}$ & $\begin{array}{c}\text { Pelvic pain, } \\
\text { vaginal bleeding }\end{array}$ & Uterine LM \\
\hline 13 & Api et al. (2009) (11) & 45 & 2 & None & EM polyp & Hypermenorrhea & $\begin{array}{l}\text { Fibroma or } \\
\text { thecoma }\end{array}$ \\
\hline 14 & Carinelli et al. (2009) (12) & 39 & NA & None & Multiple adenomyomas & LAP, dysmenorrhea & Acute appendicitis \\
\hline 15 & Mandal et al. (2009) (13) & 60 & NA & None & Menopause & Pelvic pain & Ovarian cancer \\
\hline 16 & Kim et al. (2011) (14) & 39 & 0 & None & LM, moderate ascites & LAP & Ovarian cancer \\
\hline 17 & Present study & 43 & 0 & None & $\begin{array}{l}\mathrm{LM} \text {, endometriosis, } \\
\text { infertility }\end{array}$ & $\begin{array}{l}\text { LAP, dyspareunia, } \\
\text { menometrorrhagia }\end{array}$ & $\begin{array}{c}\text { Endometriotic cyst } \\
\text { or hydrosalpinx }\end{array}$ \\
\hline 18 & & 35 & 1 & None & $\begin{array}{l}\text { LM, EM polyp, } \\
\text { endometriosis }\end{array}$ & $\begin{array}{l}\text { LAP, menorrhagia, } \\
\text { hypermenorrhea }\end{array}$ & Endometriotic cyst \\
\hline 19 & & 45 & 0 & None & LM, endometriosis & None & NA \\
\hline
\end{tabular}

NA: Not applicable; EM: endometrium; LM: leiomyoma; LAP: low abdominal pain.

partly surrounded by non-neoplastic ovarian parenchyma. Each mass was composed of an outer muscular wall of variable thickness and a central cavity containing serosanguinous fluid or blood clots. The cut surface of the outer wall was tan-white and trabeculated in appearance. Histologically, the masses had well-circumscribed outlines that were completely separated from the uninvolved ovarian parenchyma. The central cavities were lined by endometrialtype glands and stroma, which were surrounded by wellformed smooth muscles. Small endometrial-type glands and stroma were scattered within the outer smooth muscle layer. Although most of the endometrial-type glands were surrounded by stroma, in some areas the stroma varied in thickness or was absent. Immunohistochemical staining demonstrated strong cytokeratin 7 and epithelial membrane antigen expression in the glandular epithelium. CD10 staining was strongly positive for endometrial-type stromal cells and some smooth muscle cells. Smooth muscle actin staining was positive for smooth muscle cells and patchy positive for endometrial-type stromal cells. However, staining of caldesmon, muscle-specific actin, and desmin was positive for smooth muscle cells, but negative for endometrial-type stromal cells. Estrogen and progesterone receptors were uniformly found in glandular, stromal, and muscular components. Staining for inhibin- $\alpha$ was positive in the residual ovarian parenchyma. Ki-67 labeling indices were less than $1 \%$ in glandular, stromal, and muscular components. Representative photomicrographs are shown in Figure 1.

Clinical features of primary ovarian adenomyoma. Table I summarizes the clinical features of 16 previously reported cases (cases 1-9, and11-14) and our three cases of primary ovarian adenomyoma. Sixteen $(84.2 \%)$ out of the 19 patients were of childbearing age within the fourth decade of life. The median age of patients was 38 years (range $=11-60$ years). One $(5.3 \%$; 11 years old) patient was premenarchal and two (10.5\%; 54 and 60 years old) were postmenopausal. Previous 

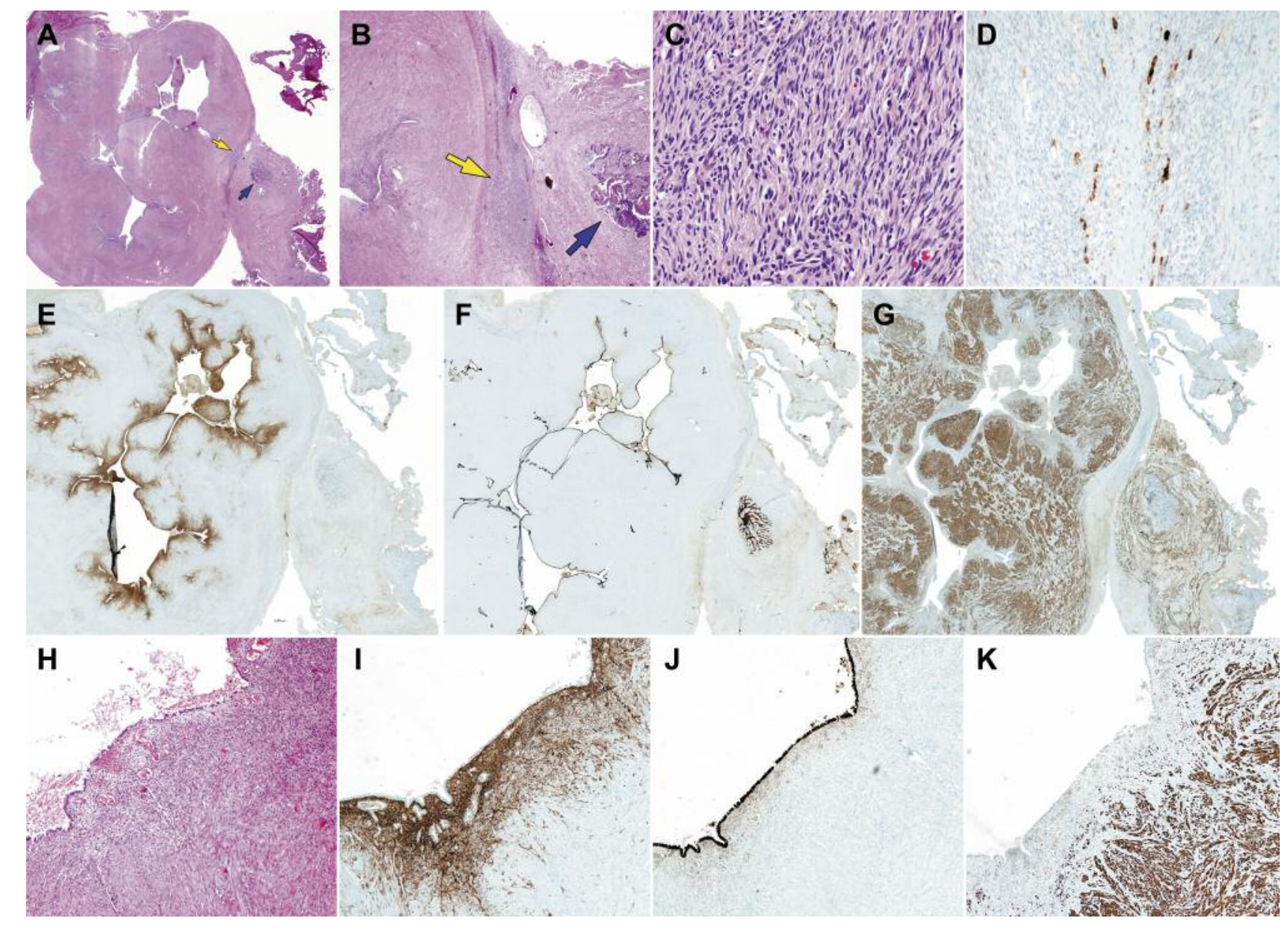

Figure 1. Histopathological and immunohistochemical findings of primary ovarian adenomyoma. A: Scanning view of hematoxylin and eosin staining revealed a well-circumscribed, slightly lobulated tumor tissue possessing a central cystic space. The muscular wall varies in thickness. Between the ovarian tumor and normal-appearing fallopian tube (small blue arrow), the uninvolved, residual ovarian parenchyma (small yellow arrow) is noted. B: Compressed ovarian cortical tissue (large yellow arrow) is located between the ovarian adenomyoma (left half) and fallopian tube (right half; large blue arrow). C: High-power view of residual ovarian parenchyma reveals benign-appearing stromal cells. D: Inhibin- $\alpha$ staining is positive in the ovarian parenchyma. Immunohistochemically, the endometrial-type stroma, endometrial-type epithelium, and muscular wall are highlighted by staining for CD10 (E), cytokeratin $7(F)$, and smooth muscle actin $(G)$. H: Medium-power view of the inner aspect of the muscular wall reveals endometrial-type epithelium and underlying stroma. I: CD10 highlights the endometrial-type stroma, which appears to radiate irregularly into the smooth muscle layer. Some smooth muscle cells are also positive for CD10. J: Cytokeratin 7 highlights a single layer of endometrial-type epithelial cells. K: Smooth muscle actin immunostaining confirms the nature of muscular wall. Scattered endometrial-type stromal cells are also immunoreactive for smooth muscle actin.

obstetric histories were available for $15(78.9 \%)$ patients; five $(33.3 \%)$ patients had experienced at least one pregnancy. Of the 19 patients, congenital anomalies were identified in three $(15.8 \%)$ patients, all of which were urinary tract anomalies including unilateral renal agenesis, unilateral pelvic kidney, double renal excretory system, double ureter, ureteral reimplantation, and vesicoureteral reflux. The majority $(17 / 19 ; 89.5 \%)$ of patients presented with at least one clinical symptom; six (31.6\%) patients presented with two or more symptoms. The most common clinical presentation was abdominal/pelvic pain $(12 / 19 ; 63.2 \%)$, followed by abnormal menstruation $(5 / 19 ; 26.3 \%)$. Other symptoms included palpable mass, dyspareunia, and infertility. In four (21\%) out of the 19 patients, endometriosis was identified in residual ovarian parenchyma. Presumptive clinical diagnoses were described for $10(52.6 \%)$ patients, and ovarian malignancy was suspected in four $(40.0 \%)$ patients.

Table II summarizes imaging findings of ovarian adenomyoma. Radiological images were available for interpretation in 15 cases: transvaginal ultrasonography in 11, computed tomography in three, and magnetic resonance imaging in one. The ovarian adenomyomas showed non- 
Table II. Imaging findings, treatment, and follow-up data of primary ovarian adenomyoma.

\begin{tabular}{|c|c|c|c|c|c|}
\hline \multirow[t]{2}{*}{ Case } & \multicolumn{2}{|c|}{ Imaging findings } & \multirow[t]{2}{*}{ Treatment } & \multirow[t]{2}{*}{ Follow-up period } & \multirow[t]{2}{*}{ Current status } \\
\hline & Modality & Characteristics & & & \\
\hline 1 & NA & NA & NA & NA & NA \\
\hline 2 & US & Cystic mass & Excision & NA & NA \\
\hline 3 & US & Solid and cystic mass & $\mathrm{TAH}+\mathrm{RSO}$ & NA & NA \\
\hline 4 & US & Solid and cystic mass & TAH+BSO & NA & NA \\
\hline 5 & US & Solid and cystic mass & $\mathrm{TAH}+\mathrm{BSO}$ & NA & NA \\
\hline 6 & NA & NA & $\mathrm{TAH}+\mathrm{LSO}$ & NA & NA \\
\hline 7 & US & Cystic mass & Excision & 17 Months & NED \\
\hline 8 & NA & Solid mass & Excision & 12 Months & NED \\
\hline 9 & $\mathrm{CT}$ & Solid and cystic mass & Completion hysterectomy+LO+omentectomy & NA & NA \\
\hline 10 & US & Cystic mass & RSO & NA & NA \\
\hline 11 & NA & NA & Excision & NA & NA \\
\hline 12 & US & Solid and cystic mass & $\mathrm{TAH}+\mathrm{BSO}$ & NA & NA \\
\hline 13 & US & Solid and cystic mass & $\mathrm{TAH}+\mathrm{BSO}$ & NA & NA \\
\hline 14 & NA & NA & Appendectomy+RO+GnRH agonist therapy & 10 Years & SD \\
\hline 15 & US & Solid and cystic mass & TAH+BSO+omental biopsy & NA & NA \\
\hline 16 & $\mathrm{CT}$ & Solid and cystic mass & Excision & 1.5 Months & NED \\
\hline 17 & US & Solid and cystic mass & TAH+LSO & 21 Months & NED \\
\hline 18 & MRI & Cystic mass & TAH+LO WR+LS & 12 Months & NED \\
\hline 19 & $\mathrm{CT}$ & Cystic mass & $\mathrm{TAH}+\mathrm{RO} \mathrm{WR}+\mathrm{RS}+\mathrm{LSO}$ & 5 Months & NED \\
\hline
\end{tabular}

NA: Not applicable; US: ultrasonography; CT: computed tomography; MRI: magnetic resonance imaging; TAH: total abdominal hysterectomy; BSO: bilateral salpingo-oophorectomy; LSO: left salpingo-oophorectomy; LO: left oophorectomy; RSO: right salpingo-oophorectomy; RO: right oophorectomy; GnRH: gonadotropin-releasing hormone; WR: wedge resection; NED: no evidence of disease; SD: stable disease.

specific imaging features, although in nine $(60.0 \%)$ cases they presented as mixed solid and cystic masses. Five $(33.3 \%)$ and one $(6.7 \%)$ cases were interpreted as cystic and solid masses, respectively. Accordingly, there were no cases preoperatively suspected as being ovarian adenomyoma according to the radiological reports.

Treatment records were available for $18(94.7 \%)$ patients (Table II). Total hysterectomy with unilateral or bilateral salpingo-oophorectomy was performed in 11 of the 18 patients. Eight of the 11 patients had uterine pathologies, including leiomyoma $(5 / 11 ; 45.4 \%)$, endometrial polyp $(2 / 11 ; 18.2 \%)$, endometrial endometrioid carcinoma $(1 / 11$; $9.1 \%)$, and adenomyosis $(1 / 11 ; 9.1 \%)$. The remaining seven patients underwent unilateral oophorectomy, salpingooophorectomy, or ovarian mass excision. Although clinical follow-up data were available for seven patients, no recurrences after surgical treatment were reported (Table II).

Histopathological features of primary ovarian adenomyoma. Table III summarizes the histopathological features of 19 primary ovarian adenomyoma cases (cases 1-14). The majority of cases presented as a single mass involving one ovary $(18 / 19 ; 94.7 \%)$. The size of the masses varied, which ranged from $0.7-13 \mathrm{~cm}$. The typical gross appearance was a well-circumscribed, ovoid, nodular mass resembling the uterus. A central cavity surrounded by thick muscular wall was the most commonly observed appearance of the cut surface $(17 / 19 ; 89.5 \%)$. The appearance of the cut surface was not described in two $(10.5 \%)$ cases. The nature of the cavity content varied: chocolate-like, brown, bloody, serosanguinous, serous, viscous, and serosanguinous. Blood clots were often observed. Comments regarding the presence of residual ovarian parenchyma were made in $13(68.4 \%)$ cases. In $11(84.6 \%)$ out of the 13 cases, residual ovarian parenchyma was identified. The size of the mass in the remaining two cases was 6 and $11.5 \mathrm{~cm}$, respectively. Ovarian adenomyoma typically displayed zonal distributions of three histological components: endometrial-type glands in the innermost part of the mass, endometrial-type stroma in the mid-zone, and smooth muscles in the outermost part. Unusual histopathological findings were observed: mucinous or tubal metaplasia in the glandular epithelium, lack of stromal component, and grade 1 endometrioid carcinoma.

\section{Discussion}

Since Cozzutto et al. first described an ovarian mass occurring in a 31-year-old woman as a uterus-like mass in 1981 (1), subsequent cases of extrauterine adenomyoma have been reported variously as "uterus-like mass", "extrauterine 
Table III. Pathological features of primary ovarian adenomyoma.

\begin{tabular}{|c|c|c|c|c|c|c|c|c|}
\hline Case & $\begin{array}{l}\text { Location } \\
\text { of tumor }\end{array}$ & $\begin{array}{l}\text { Number of } \\
\text { tumors }\end{array}$ & $\begin{array}{l}\text { Greatest } \\
\text { dimension } \\
\text { of tumor }\end{array}$ & $\begin{array}{l}\text { Gross or intraoperative } \\
\text { appearance of tumor }\end{array}$ & $\begin{array}{l}\text { Histopathological } \\
\text { diagnosis }\end{array}$ & $\begin{array}{l}\text { Residual } \\
\text { ovarian } \\
\text { parenchyma }\end{array}$ & $\begin{array}{l}\text { Unusual } \\
\text { histopathological } \\
\text { findings }\end{array}$ & IHC \\
\hline 1 & $\begin{array}{l}\text { Left } \\
\text { ovary }\end{array}$ & Single & $6 \mathrm{~cm}$ & $\begin{array}{l}\text { Central, round cavity containing } \\
\text { chocolate-like fluid and thick } \\
\text { cyst wall with fasciculated, } \\
\text { whorled appearance, } \\
\text { resembling leiomyoma }\end{array}$ & Uterus-like mass & Absent & None & NA \\
\hline 2 & $\begin{array}{l}\text { Right } \\
\text { ovary }\end{array}$ & $\begin{array}{c}\text { Single } \\
\text { (bilobated) }\end{array}$ & $\begin{array}{c}9 \mathrm{~cm} \\
\text { (larger lobe), } \\
4 \mathrm{~cm} \\
\text { (smaller lobe) }\end{array}$ & $\begin{array}{c}\text { Thin-walled cyst with chocolate- } \\
\text { like fluid and Fibrous septae } \\
\text { (larger lobe), thick-walled mass } \\
\text { with central cavity, } \\
\text { resembling uterus } \\
\text { (smaller lobe) }\end{array}$ & Uterus-like mass & $\begin{array}{l}\text { Present } \\
\text { (compressed } \\
\text { at the } \\
\text { periphery) }\end{array}$ & $\begin{array}{l}\text { No endometrial- } \\
\text { type stroma }\end{array}$ & NA \\
\hline 3 & $\begin{array}{l}\text { Right } \\
\text { ovary }\end{array}$ & Single & $\begin{array}{c}2.8 \mathrm{~cm} \\
(\text { nodule) } \\
9.5 \mathrm{~cm} \text { (cyst) }\end{array}$ & $\begin{array}{l}\text { Chocolate cyst with } \\
\text { intracystic mural nodules } \\
\text { Protruding into the lumen }\end{array}$ & Uterus-like mass & Present & $\begin{array}{l}\text { Smooth muscle } \\
\text { localized within } \\
\text { the nodule only }\end{array}$ & NA \\
\hline 4 & $\begin{array}{l}\text { Right } \\
\text { ovary }\end{array}$ & $\begin{array}{c}\text { Single } \\
\text { (bilobated) }\end{array}$ & $\begin{array}{c}9 \mathrm{~cm} \\
\text { (larger lobe), } \\
5 \mathrm{~cm} \\
\text { (smaller lobe) }\end{array}$ & $\begin{array}{c}\text { Multilocular cyst containing } \\
\text { friable tissue and Blood } \\
\text { (larger lobe), thick-walled } \\
\text { mass with central cavity, } \\
\text { resembling uterus (smaller lobe) }\end{array}$ & Uterus-like mass & $\begin{array}{c}\text { Present } \\
\text { (outer aspect) }\end{array}$ & $\begin{array}{l}\text { Endometrioid } \\
\text { carcinoma } \\
(\text { grade } 1)\end{array}$ & SMA (P) \\
\hline 5 & $\begin{array}{l}\text { Right } \\
\text { ovary }\end{array}$ & Single & $8 \mathrm{~cm}$ & $\begin{array}{l}\text { A central chocolate cyst and } \\
\text { an outer fasciculated tissue } \\
\text { resembling leiomyoma }\end{array}$ & Endomyometriosis & NA & None & $\operatorname{del}(2)(\mathrm{p} 21)$ \\
\hline 6 & $\begin{array}{c}\text { Left } \\
\text { ovary }\end{array}$ & Single & $2 \mathrm{~cm}$ & Well-circumscribed nodule & Uterus-like mass & $\begin{array}{c}\text { Present } \\
\text { (serosal aspect) }\end{array}$ & None & NA \\
\hline 7 & $\begin{array}{l}\text { Bilateral } \\
\text { ovaries }\end{array}$ & $\begin{array}{l}\text { Single } \\
\text { (right), } \\
\text { single } \\
\text { (left) }\end{array}$ & $\begin{array}{l}4 \mathrm{~cm} \\
(\text { right), } \\
4 \mathrm{~cm} \\
(\text { left })\end{array}$ & $\begin{array}{l}\text { A cavity with yellow material } \\
\text { (right), thick-walled cyst with } \\
\text { brown grumous material and } \\
\text { a firm, well-circumscribed mass } \\
\text { resembling uterus (left) }\end{array}$ & Uterus-like mass & $\begin{array}{c}\text { Present } \\
\text { (large amount) }\end{array}$ & None & NA \\
\hline 8 & $\begin{array}{l}\text { Right } \\
\text { ovary }\end{array}$ & Single & $11.5 \mathrm{~cm}$ & $\begin{array}{l}\text { Thick-walled cystic mass with } \\
\text { trabeculated, gray-to-brown outer } \\
\text { surface, rough, red-to- brown inner } \\
\text { surface, and hemorrhagic, cleft- } \\
\text { like spaces within the wall }\end{array}$ & Uterus-like mass & Absent & None & $\begin{array}{l}\text { CK }(\mathrm{P}) \\
\text { DES }(\mathrm{P}) \\
\text { EMA }(\mathrm{P}) \\
\text { SMA (P), } \\
\text { VIM (P) }\end{array}$ \\
\hline 9 & $\begin{array}{c}\text { Left } \\
\text { ovary }\end{array}$ & Single & $13 \mathrm{~cm}$ & $\begin{array}{l}\text { Large ovarian cyst with chocolate- } \\
\text { like fluid, shaggy outer surface }\end{array}$ & Uterus-like mass & $\begin{array}{l}\text { Present } \\
\text { (at the periphery }\end{array}$ & None & NA \\
\hline 10 & $\begin{array}{c}\text { Left } \\
\text { ovary }\end{array}$ & Single & $4.5 \mathrm{~cm}$ & $\begin{array}{l}\text { Well-circumscribed, firm, tan-to- } \\
\text { pink, thick- walled, smooth-lined } \\
\text { cystic mass }\end{array}$ & Uterus-like mass & Present & None & NA \\
\hline 11 & $\begin{array}{l}\text { Right } \\
\text { ovary }\end{array}$ & Single & $0.7 \mathrm{~cm}$ & $\begin{array}{l}\text { A nodular lesion within the } \\
\text { ovarian stroma in close } \\
\text { proximity to corpus albicans }\end{array}$ & Uterus-like mass & Present & $\begin{array}{l}\text { Tubal } \\
\text { metaplasia }\end{array}$ & None \\
\hline 12 & $\begin{array}{c}\text { Left } \\
\text { ovary }\end{array}$ & Single & NA & $\begin{array}{l}\text { Smooth outer surface, no adhesion, } \\
\text { foci of Endometrium inside the } \\
\text { smooth muscle, dark brown viscous } \\
\text { fluid, firm and white cyst lining }\end{array}$ & Adenomyoma & NA & $\begin{array}{c}\text { Focal } \\
\text { mucinous } \\
\text { differentiation }\end{array}$ & $\begin{array}{l}\text { ER }(\mathrm{P}) \\
\text { FSH }(\mathrm{N}) \\
\text { LH }(\mathrm{N}) \\
\text { PgR }(\mathrm{P})\end{array}$ \\
\hline 13 & $\begin{array}{c}\text { Left } \\
\text { ovary }\end{array}$ & Single & NA & Enlarged, gray-to-white, firm mass & Adenomyoma & NA & None & $\begin{array}{l}\text { DES }(\mathrm{P}) \\
\mathrm{INH}(\mathrm{N}) \\
\operatorname{MSA}(\mathrm{P})\end{array}$ \\
\hline 14 & $\begin{array}{l}\text { Right } \\
\text { ovary }\end{array}$ & Single & $3.5 \mathrm{~cm}$ & $\begin{array}{l}\text { Well-encapsulated, multinodular } \\
\text { cystic mass With thick, white-tan } \\
\text { cystic wall and brown fluid }\end{array}$ & Adenomyoma & NA & $\begin{array}{c}\text { Multiple } \\
\text { foci of } \\
\text { endometriosis }\end{array}$ & NA \\
\hline 15 & $\begin{array}{l}\text { Left } \\
\text { ovary }\end{array}$ & Single & $9 \mathrm{~cm}$ & $\begin{array}{l}\text { Smooth outer surface, solid and } \\
\text { cystic areas filled with serous fluid }\end{array}$ & Adenomyoma & NA & $\begin{array}{l}\text { No endometrial } \\
\text { stroma, focal } \\
\text { intraluminal } \\
\text { mucin }\end{array}$ & $\begin{array}{l}\text { EMA }(\mathrm{P}) \\
\text { CK }(\mathrm{P}) \\
\text { SMA }(\mathrm{P})\end{array}$ \\
\hline
\end{tabular}


Table III. Continued

\begin{tabular}{|c|c|c|c|c|c|c|c|c|}
\hline Case & $\begin{array}{l}\text { Location } \\
\text { of tumor }\end{array}$ & $\begin{array}{l}\text { Number of } \\
\text { tumors }\end{array}$ & $\begin{array}{l}\text { Greatest } \\
\text { dimension } \\
\text { of tumor }\end{array}$ & $\begin{array}{l}\text { Gross or intraoperative } \\
\text { appearance of tumor }\end{array}$ & $\begin{array}{c}\text { Histopathological } \\
\text { diagnosis }\end{array}$ & $\begin{array}{c}\text { Residual } \\
\text { ovarian } \\
\text { parenchyma }\end{array}$ & $\begin{array}{l}\text { Unusual } \\
\text { histopathological } \\
\text { findings }\end{array}$ & IHC \\
\hline 16 & $\begin{array}{l}\text { Left } \\
\text { ovary }\end{array}$ & Single & $12.5 \mathrm{~cm}$ & $\begin{array}{l}\text { White, solid, and whirling cut } \\
\text { surface (firm area), multiple cysts } \\
\text { filled with serosanguinous fluid } \\
\text { and blood clots (soft area) }\end{array}$ & Adenomyoma & NA & None & $\begin{array}{l}\text { DES (P), } \\
\text { SMA (P), } \\
\text { VIM (P) }\end{array}$ \\
\hline 17 & $\begin{array}{l}\text { Left } \\
\text { ovary }\end{array}$ & Single & $4.7 \mathrm{~cm}$ & $\begin{array}{c}\text { Well-circumscribed, ovoid, } \\
\text { white, rubbery mass with a } \\
\text { central cavity and trabeculated, } \\
\text { blood tinged cut surface }\end{array}$ & Adenomyoma & $\begin{array}{l}\text { Present } \\
\text { (at the } \\
\text { periphery) }\end{array}$ & None & $\begin{array}{c}\text { CK (P), } \\
\text { CD10 (P), } \\
\text { DES (P), } \\
\text { CDS (P) } \\
\text { EMA (P), } \\
\text { ER (P), } \\
\text { MSA (P), } \\
\text { PgR (P), } \\
\text { SMA (P), } \\
\text { Ki-67 } \\
\text { (less than } \\
1 \%)\end{array}$ \\
\hline 18 & $\begin{array}{c}\text { Left } \\
\text { ovary }\end{array}$ & Single & $1.7 \mathrm{~cm}$ & $\begin{array}{l}\text { Well-circumscribed, ovoid, } \\
\text { tan-yellow, rubbery mass with a } \\
\text { central cavity containing } \\
\text { serosanguinous fluid and outer wall } \\
\text { with trabeculated surface }\end{array}$ & Adenomyoma & $\begin{array}{l}\text { Present } \\
\text { (at the } \\
\text { periphery) }\end{array}$ & None & \\
\hline 19 & $\begin{array}{l}\text { Right } \\
\text { ovary }\end{array}$ & Single & $0.8 \mathrm{~cm}$ & $\begin{array}{l}\text { Well-circumscribed, ovoid, white, } \\
\text { rubbery mass with a central cavity } \\
\text { containing blood clot and thick, } \\
\text { tan-white cystic wall }\end{array}$ & Adenomyoma & Present & None & \\
\hline
\end{tabular}

NA: Not applicable; IHC: immunohistochemistry; SMA: smooth muscle actin; CK: cytokeratin; DES: desmin; EMA: epithelial membrane antigen; VIM: vimentin; ER: estrogen receptor; FSH: follicle-stimulating hormone; LH: luteinizing hormone; PgR: progesterone receptor; INH: inhibin- $\alpha$; MSA: muscle-specific actin; CDS: caldesmon.

adenomyoma", or "endomyometriosis", reflecting different opinions about the pathogenesis of this neoplasm $(2,9,12)$. The reported cases demonstrated various sites of involvement, including both gynecological nongynecological organs. To date, 51 cases of extrauterine adenomyoma have been reported in the English literature.

This study was aimed at comprehensively describing the clinical and histopathological features of ovarian adenomyoma. Patient demographics and clinical symptoms of ovarian adenomyoma are relatively non-specific, since common gynecological diseases occurring in women of childbearing age such as adenomyosis, leiomyoma, or endometriosis can cause abdominal pain and discomfort, as well as irregular menstruation. Regardless of the presumptive clinical diagnosis made based on clinical presentation, imaging findings of ovarian adenomyoma are noteworthy because the presence of a solid component, septum, and heterogeneous signals within the ovarian cystic mass raise suspicions of malignancy. In three previous cases, the treatment options were selected based on clinical suspicion of ovarian cancer $(7,13,14)$. If women of reproductive age present with solid or cystic ovarian masses and typical symptoms of endometriosis, it is worthwhile considering the possibility of ovarian adenomyoma, although ancillary studies may indicate malignancy. Frozen-section examinations to exclude rare benign ovarian neoplasms mimicking malignancy may merit therapeutic approaches. Histopathological examinations of ovarian adenomyoma generally do not cause diagnostic dilemmas because the morphological and immunohistochemical findings are obviously different from those of ovarian cancer. In contrast, ovarian adenomyoma exhibits the same morphology and immunophenotype as normal endomyometrium. A possible exception to this generalization is the development of malignancy in ovarian adenomyoma, as one case of endometrioid carcinoma arising in ovarian adenomyoma has been reported (4).

To date, 32 cases of extrauterine, non-ovarian adenomyoma have been reported (15-35, 46-52). In patients with extrauterine, non-ovarian adenomyoma, the majority $(30 / 32 ; 93.8 \%)$ of patients were women of childbearing age, 
and the remaining two $(6.3 \%)$ were men. Similar to ovarian adenomyoma, abdominal/pelvic pain and discomfort and irregular menstruation were common clinical presentations of extrauterine, nonovarian adenomyoma. Some patients presented with site-specific symptoms: constipation in patients with intestinal lesions $(31,35)$, back pain and paresthesia in those with spinal lesions (28-30), and palpable masses in those with a testicular lesion (52), a nodal lesion (49), or inguinal lesions $(46,50)$. Endometriosis was the most commonly associated condition. Anomalous gastrointestinal or urinary tract lesions were found in a few cases (31). All patients with conus medullaris lesions exhibited spinal dysraphism (28-30). Local excision was curative in most cases, but segmental resection of the intestine was performed in cases involving the intestinal wall or mesentery. Interestingly, there has been one case of extrauterine, nonovarian adenomyoma-associated malignancy (27). A 67-year-old woman was diagnosed with clear-cell carcinoma arising in the retroperitoneal adenomyoma. She did not undergo surgery at the time of diagnosis. After 14 years, the radiological signs of mass enlargement and suspected malignant transformation led to excision. To the best of our knowledge, there have been only two cases of epithelial malignancy arising in extrauterine adenomyoma, one of which was endometrioid carcinoma arising in the ovarian adenomyoma and the other clear cell carcinoma arising in the retroperitoneal adenomyoma $(4,27)$. Most patients with extrauterine adenomyoma complain of tumor-related symptoms and require surgical treatment at the time of diagnosis. However, even in asymptomatic patients, surgical treatment should be considered due to the rare chance of malignant transformation.

Primary ovarian neoplasm containing smooth muscle component is uncommon, which follows logically from the lack of a smooth muscle component in ovarian parenchyma. Since the first case of extrauterine adenomyoma was reported, three hypotheses regarding the pathogenesis have been suggested: congenital anomaly (53), heterotopia (30), and metaplasia (1). In patients without congenital anomalies or spinal cord lesions that is barely involved by endometriosis, the metaplasia hypothesis is the most widely accepted. Smooth muscle metaplasia in ovarian endometriosis is well known (54). Many authors postulate that ovarian endometriosis functions as the substrate for the development of adenomyoma. This hypothesis is linked to the observation that endometriosis is found in patients with ovarian adenomyoma. In the present study, immunohistochemical staining revealed CD10-positive smooth muscle cells and smooth muscle actin-positive endometrial-type stromal cells within the masses, suggesting a possible link between the two cell types. Smooth muscle metaplasia in endometriosis is regarded as a consequence of repeated tissue injury and repair, mediated by epthelial- mesenchymal transition and fibroblast-to-myofibroblast transdifferentiation (55). Zhang et al. demonstrated that myofibroblasts and highly differentiated smooth muscle cells increase in the stromal compartment as endometriosis progresses, in association with increases of transforming growth factor- $\beta 1$ and Smad-3, which mediate the metaplastic process (56). Therefore, the interpretation of pathogenesis in our series is most compatible with the metaplastic theory.

In summary, we demonstrated the clinicopathological characteristics of primary ovarian adenomyoma. We provided a thorough review of previously published case reports and described three additional cases of primary ovarian adenomyoma. Ovarian adenomyoma is a benign neoplasm of the ovary that can be treated by simple surgical excision. However, it can be sometimes misinterpreted as primary ovarian malignancy during imaging studies, leading clinicians to perform unnecessary treatments. Ovarian adenomyoma exhibits distinct histopathological features; it does not typically cause diagnostic dilemmas because the morphological findings are obviously different from those of ovarian cancer. However, clinicians and pathologists should be aware of the possible development of malignancy within the glandular component and carefully examine the entire lesion.

\section{Acknowledgements}

This research was supported by the Basic Science Research Program through the National Research Foundation of Korea (NRF) funded by the Ministry of Education (2016R1D1A1B03935584) and by a faculty research grant from Yonsei University College of Medicine for 2016 (6-2016-0130).

\section{References}

1 Cozzutto C: Uterus-like mass replacing ovary: report of a new entity. Arch Pathol Lab Med 105: 508-511, 1981.

2 Pueblitz-Peredo S, Luevano-Flores E, Rincon-Taracena R and Ochoa-Carrillo FJ: Uteruslike mass of the ovary: Endomyometriosis or congenital malformation? A case with a discussion of histogenesis. Arch Pathol Lab Med 109: 361-364, 1985.

3 McDougal RA and Roth LM: Ovarian adenomyoma associated with an endometriotic cyst. South Med J 79: 640-642, 1986.

4 Rahilly MA and al-Nafussi A: Uterus-like mass of the ovary associated with endometrioid carcinoma. Histopathology 18 : 549-551, 1991.

5 Verhest A, Simonart $\mathrm{T}$ and Noel JC: A unique clonal chromosome 2 deletion in endomyometriosis. Cancer Genet Cytogenet 86: 174-176, 1996.

6 Mitra S, Nicol A and Scott GI: Uterus-like mass of the ovary. J Obstet Gynaecol 17: 94-95, 1997.

7 Pai SA, Desai SB and Borges AM: Uterus-like masses of the ovary associated with breast cancer and raised serum CA-125. Am J Surg Pathol 22: 333-337, 1998.

8 Shutter J: Uterus-like ovarian mass presenting near menarche. Int J Gynecol Pathol 24: 382-384, 2005. 
9 Bayar U, Demirtas E, Usubutun A, Basaran M, Esinler I and Yarali $\mathrm{H}$ : Ovarian adenomyoma following gonadotrophin treatment for infertility. Reprod Biomed Online 13: 676-679, 2006.

10 Gurel D, Tuna B and Yorukoglu K: Uterus-like mass of the ovary. Turk J Pathol 23: 103-106, 2007.

11 Api O, Ergen B, Gul AE, Ergen C, Unal O and Turan C: Primary ovarian adenomyoma in a woman with endometrial polyp: a case report and review of the literature. Arch Gynecol Obstet 280: 445-448, 2009.

12 Carinelli S, Motta F, Frontino G, Restelli E and Fedele L: Multiple extrauterine adenomyomas and uterus-like masses: case reports and review of the literature. Fertil Steril 91: 1956.e19591911, 2009.

13 Mandal S, Mahajan D and Khurana N: Ovarian adenomyoma mimicking an ovarian malignancy: a case report with literature review. Int J Surg Pathol 17: 38-40, 2009.

14 Kim JO, Baek JM, Jeung C, Park EK, Lee HN and Lee YS: A case of primary ovarian adenomyoma mimicking ovarian malignancy. Eur J Gynaecol Oncol 32: 103-106, 2011.

15 Pai RR, Sharma L, Pinto PJ and Raghuveer CV: Endomyometriosis. J Indian Med Assoc 93: 326, 1995.

16 Ahmed AA, Swan RW, Owen A, Kraus FT and Patrick F: Uterus-like mass arising in the broad ligament: A metaplasia or mullerian duct anomaly? Int J Gynecol Pathol 16: 279-281, 1997.

17 Matsuzaki S, Murakami T, Sato S, Moriya T, Sasano H and Yajima A: Endomyometriosis arising in the uterosacral ligament: a case report including a literature review and immunohistochemical analysis. Pathol Int 50: 493-496, 2000.

18 Liang YJ, Hao Q, Wu YZ and Wu B: Uterus-like mass in the left broad ligament misdiagnosed as a malformation of the uterus: a case report of a rare condition and review of the literature. Fertil Steril 93: 1347.e1313-1346, 2010.

19 Takeda A, Imoto S, Mori M, Yamada J and Nakamura H: Uterus-like mass of ovarian ligament: Image diagnosis and management by laparoendoscopic single-site surgery. J Obstet Gynaecol Res 37: 1895-1899, 2011.

20 Sisodia SM, Khan WA and Goel A: Ovarian ligament adenomyoma: report of a rare entity with review of the literature. J Obstet Gynaecol Res 38: 724-728, 2012.

21 Nechi S, Znaidi N, Rammah S, M'Farej M K and Zermani R: Uterus-like mass of the broad ligament. Int J Gynaecol Obstet 123: 249-250, 2013.

$22 \mathrm{Ko}$ JK and Cheung VY: Uterus-like mass: issues on pathogenesis. J Minim Invasive Gynecol 22: 1133-1134, 2015.

$23 \mathrm{He} \mathrm{J}, \mathrm{Xu} \mathrm{J}$ and Zhou HY: Uterus-like mass: A very rare and elusive entity a case report. Medicine 95: e4961, 2016.

24 Kaufman Y and Lam A: The pelvic uterus-like mass--a primary or secondary Mullerian system anomaly? J Minim Invasive Gynecol 15: 494-497, 2008.

25 Khurana A, Mehta A and Sardana M: Extrauterine adenomyoma with uterus like features: a rare entity presenting 17 years post hysterectomy. Indian J Pathol Microbiol 54: 572-573, 2011.

26 Carvalho FM, Carvalho JP, Pereira RM, Ceccato BP Jr., Lacordia R and Baracat EC: Leiomyomatosis peritonealis disseminata associated with endometriosis and multiple uteruslike mass: report of two cases. Clin Med Insights Case Rep 5: 63-68, 2012

27 Nakakita B, Abiko K, Mikami Y, Kido A, Baba T, Yoshioka Y, Yamaguchi K, Matsumura $\mathrm{N}$ and Konishi I: Clear-cell carcinoma arising from a uterus-like mass. Pathol Int 64: 576$580,2014$.

28 Kakkar A, Sharma MC, Garg A, Goyal N, Suri V, Sarkar C and Mahapatra AK: Uterus-like mass in association with neural tube defect: a case report and review of the literature. Pediatr Neurosurg 48: 240-244, 2012.

29 Rougier A, Vital C and Caillaud P: Uterus-like mass of the conus medullaris with associated tethered cord. Neurosurgery 33: 328331, 1993.

30 Sharma MC, Sarkar C, Jain D, Suri V, Garg A and Vaishya S: Uterus-like mass of mullerian origin in the lumbosacral region causing cord tethering. Report of two cases. J Neurosurg Spine 6: 73-76, 2007.

31 Peterson CJ, Strickler JG, Gonzalez R and Dehner LP: Uteruslike mass of the small intestine. Heterotopia or monodermal teratoma? Am J Surg Pathol 14: 390-394, 1990.

32 Horie $\mathrm{Y}$ and Kato M: Uterus-like mass of the small bowel mesentery. Pathol Int 50: 76-80, 2000.

33 Shin SY, Kim HJ, Kim YW and Lee KY: CT characteristics of a uterus-like mass in the sigmoid mesocolon. Br J Radiol 84: e13, 2011.

34 Kim HC, Yang DM, Kim SW, Kim GY, Choi SI and Park SJ: Uterus-like mass involving the appendix: US and CT findings. J Clin Ultrasound 40: 518-521, 2012.

$35 \mathrm{Na}$ KY, Kim GY, Won KY, Kim HS, Kim SW, Lee CH and Cha JM: Extrapelvic uterus-like masses presenting as colonic submucosal tumor: a case study and review of literature. Korean J Pathol 47: 177-181, 2013.

36 Yoon N, Yoon G, Park CK and Kim HS: Stromal p16 expression is significantly increased in malignant ovarian neoplasms. Oncotarget 7: 64665-64673, 2016.

37 Yoon G, Oh CS and Kim HS: Hypergravity upregulates renal inducible nitric oxide synthase expression and nitric oxide production. Oncotarget 7: 30147-30154, 2016.

38 Yoon G, Oh CS and Kim HS: Distinctive expression patterns of hypoxia-inducible factor-1alpha and endothelial nitric oxide synthase following hypergravity exposure. Oncotarget 7: 3367533688, 2016.

39 Kim HS, Yoon G, Do SI, Kim SJ and Kim YW: Downregulation of osteoprotegerin expression as a novel biomarker for colorectal carcinoma. Oncotarget 7: 15187-15199, 2016.

40 Bae GE, Yoon G, Song YJ and Kim HS: High-grade squamous intraepithelial lesion arising adjacent to vulvar lymphangioma circumscriptum: a tertiary institutional experience. Oncotarget 7: 48120-48129, 2016.

41 Yoon G, Kim HS, Lee YY, Kim TJ, Choi CH, Kim BG, Bae DS, Hwang JH and Lee JW: Clinical outcomes of primary surgical treatment for acquired vulvar lymphangioma circumscriptum. Arch Gynecol Obstet 293: 157-162, 2016.

42 Yoon G, Won Koh C, Yoon N, Kim JY and Kim HS: Stromal p16 expression is significantly increased in endometrial carcinoma. Oncotarget 8: 4826-4836, 2016.

43 Park CK, Yoon G, Cho YA and Kim HS: Clinicopathological and immunohistochemical characterization of papillary proliferation of the endometrium: A single institutional experience. Oncotarget 7: 39197-39206, 2016.

44 Jung YY, Nahm JH and Kim HS: Cytomorphological characteristics of glassy cell carcinoma of the uterine cervix: histopathological correlation and human papillomavirus genotyping. Oncotarget 7: 74152-74161, 2016. 
$45 \mathrm{Kim}$ EK, Yoon G and Kim HS: Chemotherapy-induced endometrial pathology: mimicry of malignancy and viral endometritis. Am J Transl Res 8: 2459-2467, 2016.

46 Gonzalez RS, Vnencak-Jones CL, Shi C and Fadare O: Endomyometriosis ("uterus-like mass") in an XY male: case report with molecular confirmation and literature review. Int $\mathrm{J}$ Surg Pathol 22: 421-426, 2014.

47 Huanwen W, Hui Z, Xiaowei X and Zhaohui L: Extrauterine adenomyoma of the liver with a focally cellular smooth muscle component occurring in a patient with a history of myomectomy: case report and review of the literature. Diagn Pathol 8: 131, 2013.

48 Redman R, Wilkinson EJ and Massoll NA: Uterine-like mass with features of an extrauterine adenomyoma presenting 22 years after total abdominal hysterectomy-bilateral salpingooophorectomy: a case report and review of the literature. Arch Pathol Lab Med 129: 1041-1043, 2005.

49 Rohlfing MB, Kao KJ and Woodard BH: Endomyometriosis: possible association with leiomyomatosis disseminata and endometriosis. Arch Pathol Lab Med 105: 556-557, 1981.

50 Seki A, Maeshima A, Nakagawa H, Shiraishi J, Murata Y, Arai $\mathrm{H}$, Kubochi $\mathrm{K}$ and Kuramochi S: A subserosal uterus-like mass presenting after a sliding hernia of the ovary and endometriosis: a rare entity with a discussion of the histogenesis. Fertil Steril 95: 1788.e1715-1789, 2011.
51 Sopha SC, Rosado FG, Smith JJ, Merchant NB and Shi C: Hepatic uterus-like mass misdiagnosed as hepatic abscess. Int $\mathrm{J}$ Surg Pathol 23: 134-139, 2015.

52 Tulunay O, Gogus C, Baltaci S and Bulut S: Clear cell adenocarcinoma of the tunica vaginalis of the testis with an adjacent uterus-like tissue. Pathol Int 54: 641-647, 2004.

53 Rosai J: Uteruslike mass replacing ovary. Arch Pathol Lab Med 106: 364-365, 1982.

54 Kim HS, Yoon G, Ha SY and Song SY: Nodular smooth muscle metaplasia in multiple peritoneal endometriosis. Int J Clin Exp Pathol 8: 3370-3373, 2015.

55 Ding D, Liu X, Duan J and Guo SW: Platelets are an unindicted culprit in the development of endometriosis: clinical and experimental evidence. Hum Reprod 30: 812-832, 2015.

56 Zhang Q, Duan J, Olson M, Fazleabas A and Guo SW: Cellular changes consistent with epithelial-mesenchymal transition and fibroblast-to-myofibroblast transdifferentiation in the progression of experimental endometriosis in baboons. Reprod Sci 23: 14091421, 2016.

Received March 1, 2017

Revised March 17, 2017

Accepted March 21, 2017 